\title{
AN INVESTIGATION OF THE RELATION BETWEEN PERSONALITY, JOB PERFORMANCE, AND JOB SATISFACTION VIA PROFILE ANALYSIS
}

\author{
Arkun Tatar ${ }^{1}$, Gaye Saltukoğlu ${ }^{1}$ \& Hüdanur Özdemir ${ }^{2}$ \\ ${ }^{I}$ Department of Psychology, FSM Vakif University / Associate Professor (Turkey) \\ ${ }^{2}$ Psychologist (Turkey)
}

\begin{abstract}
The widespread use of personality tests in the process of personnel recruitment to evaluate the suitability of applicants for a particular job and to select employees who display personality traits that are informative in terms of high performance and satisfaction, demonstrates the need for further investigation of the relation between personality, job performance and job satisfaction. In this context, the present study aimed to determine the personality traits that predict job performance and job satisfaction. For this purpose, personality profiles of the participants were compared in terms of their levels of job performance and job satisfaction, depending on the Five Factor Model. From 278 different occupational groups, 4975 people ( 2833 men and 2142 women) between the ages of 19 and 85 participated in the study. The primary criterion for inclusion was working at a job for more than one year. Personality profiles were gathered through the long form of the Five Factor Personality Inventory. In order to assess perceived job performance and job satisfaction levels, participants were asked to rate how well they find themselves successful in their work and how satisfied they are with their work on linear scales ranging from 1 to 5 with half-units of increase. In the first place, multiple linear regression analyses were conducted in order to determine effects of personality traits in predicting job performance and job satisfaction. Results showed that all of the factors are significant predictors of job satisfaction. However, Openness to Experience factor found to be ineffective in predicting job performance evaluations. In the second place, based on their job performance and job satisfaction levels subjects were categorized into four groups and personality profiles of the groups were compared with MANOVA. Results indicate that the group who has high job performance and job satisfaction differed in many personality dimensions.
\end{abstract}

Keywords: Job performance, job satisfaction, personality, personality profile, Five-Factor Model of Personality.

\section{Introduction}

The relation of personality to job performance, and job satisfaction has been the subject of much systematic investigation within the field of industrial and organizational psychology over the past century (Rothmann and Coetzer, 2003; Saltukoğlu and Tatar, 2018; Tatar, Şahintürk, Saltukoğlu and Telvi, 2013). Questions have been raised about the utility of personality measures in predicting job performance and satisfaction, especially for personnel selection purposes (Rothstein and Goffin, 2006). Early studies on the subject were conducted when there was no commonly accepted taxonomy of personality traits (Guion and Gottier, 1965; Schmitt, Gooding, Noe and Kirsch, 1984). In addition, the focus was on the validity of personality measures in occupational groups / settings, rather than investigating the effects of personality on job performance and job satisfaction in detail (Barrick and Mount, 1991). Consequently, this theoretical issue has led the conclusion that personality is not a powerful predictor of job performance and its validity is low (Guion and Gottier, 1965; Schmitt et al., 1984). However, this concept has been challenged by the emergence of the Five Factor Model of personality, which has provided more comprehensive framework (Rothmann and Coetzer, 2003; Salgado, 1997; Saltukoğlu and Tatar, 2018). The vast majority of studies, which were conducted based on the Five Factor Model, have been demonstrated that especially Conscientiousness and Emotional Stability are central factors influencing performance and satisfaction (Barrick and Mount, 1991; Barrick, Mount and Judge, 2001; Judge, Heler and Mount, 2002). 
Job performance, which is a multidimensional construct, reflects the time, energy, and resources that employees spend on tasks while fulfilling their responsibilities and it is stated that it could be affected by situational (e.g. job characteristics, structure of the organization, nature of the co-workers' interpersonal relationships) and dispositional (e.g. locus of control, self-esteem, motives, needs, achievement motivation, skills, and personality characteristics) factors (Rothmann and Coetzer, 2003). It has been reported that Conscientiousness is the strongest predictor of job performance compared to other factors (Alessandri and Vecchione, 2012; Zhao and Seibert, 2006). This finding is not surprising considering that the high end of this factor indicates being responsible, purposeful, self-disciplined, task-oriented, attentive, success oriented, determined, and trustworthy (Bhatti, Battour, Ismail, and Sundram, 2014; Somer, Korkmaz and Tatar, 2004). The second most important factor for job performance is Emotional Stability (Barrick and Mount, 1991; Zhao and Seibert, 2006). Low scores on this factor are indicative of being worried, anxious, hesitant, irritable, and unstable (Somer et al., 2004). It is stated that people who are on the low pole of this factor are vulnerable to negative life events, and when they face various problems at work their performance gets poorer, considering that they have the tendency to act accordingly (Rothmann and Coetzer, 2003).

However, research findings into Agreeableness, Extraversion and Openness to Experience have been inconsistent. This inconsistency can be explained by the fact that different jobs have and require different characteristics (Blickle et al., 2008; Costa, McCrae and Holland, 1984; Judge and Zapata, 2015; Ozer and Benet-Martinez, 2006; Saltukoğlu and Tatar, 2018; Tatar, Saltukoğlu and Teoman, 2017; Zhao and Seibert, 2006). However, it is generally reported that these factors are positively related to job performance in various occupational groups (Bhatti et al., 2014; Zhao and Seibert, 2006). Respectively, it is stated that employees who underperform are more resistant to new ideas, more conventional, less emphatic, and less inquisitive regarding the relationship between Openness to Experience and job performance. Additionally, it is suggested that employees who are at the high pole of this factor can perform better in educational settings and jobs like training (Barrick and Mount, 1991; Rothmann and Coetzer, 2003; Zhao and Seibert, 2006). Agreeableness is indicative of being open to criticisms, mild, cooperative, easygoing, helpful, and understanding and people who are at the high pole of this factor perform better in customer services or in jobs that include teamwork (Bhatti et al., 2014; Costa et al., 1984; Rothmann and Coetzer, 2003; Somer et al., 2004). Lastly, extravert people perform better in areas that include interaction with other employees or teamwork such as sales and marketing, or in managerial positions, considering that the high pole of Extraversion is reflective of positive experiences and emotions besides sociability, assertiveness, and talkativeness (Barrick, Stewart and Piotrowski, 2002; Blickle et al., 2015; Mount et al., 1998). Previous research findings into the relation between job performance and job satisfaction have been contradictory. However, it is observed that both constructs are affected by personality traits respectively and there is a strong relationship between them (Christen, Iyer and Soberman, 2006; Judge, Weiss, Kammeyer-Mueller and Hulin, 2017; Karim, 2017; Tatar, Saltukoğlu, Dal and Atay, 2013; Wright and Cropanzano, 2000). It is stated that the most important predictor of job satisfaction is Emotional Stability instead of Conscientiousness (Barrick and ark., 2001; Judge et al., 2002; Rothmann and Coetzer, 2003). Additionally, Extraversion plays an important role in predicting job satisfaction (Avery, Smillie and Fife-Schaw, 2015; Judge et al., 2002).

Regarding the inconsistency in findings, the overall aim of this study is to determine which personality traits are affective in predicting job performance and job satisfaction. In this direction, subjects from various occupational groups were compared in terms of their job performance and satisfaction levels.

\section{Method}

\subsection{Participants}

The subjects were selected on the basis of working at revenue generating jobs for more than one year (housewives, retirees, students, and people who work at charities voluntarily were excluded). Participants were 5040 people from 278 different occupations. However, the data obtained from 65 people were excluded because they did not answer questions properly. $2142(43.1 \%)$ of the participants were female and $2833(56.9 \%)$ were male, ranging in age between 19 and $85(\mathrm{M}=35.95, \mathrm{SD}=12.85)$. Working years of the participants ranged from 1 to 63 years $(M=11.82, \mathrm{SD}=11.07)$.

\subsection{Materials}

Data were collected through long form of the Five Factor Personality Inventory (Somer, Korkmaz, and Tatar, 2002; 2004) and a questionnaire to determine socio-demographic characteristics of the subjects. Long form of the Five Factor Personality Inventory is a 5-point Likert type scale (on which $1=$ Totally Accurate, $5=$ Very Inaccurate) consisting of 220 items and 17 personality dimensions. 
Employees were asked to rate how well they find themselves successful in their work and how satisfied they are with their work on a linear scale, ranged from 1 to 5 , with half-units of increase.

\subsection{Procedure and data analysis}

Data were obtained from people whom accepted to participate in the study voluntarily, using convenient sampling method in Istanbul. Data collection process lasted for about four years, and an application for one individual lasted around 30-60 minutes depending on subject's reading speed.

In the first place, the internal consistency coefficients of the Five Factor Personality Inventory's factors and dimensions were calculated for the whole group, female, and male groups separately. Afterwards, the mean scores of gender groups and the groups that were formed based on job performance and job satisfaction levels were subjected to Multivariate Analysis of Variance (MANOVA) in terms of the five factors and 17 dimensions.

\subsection{Results}

The reliability coefficients for the factors in the whole group were $0.837-0.928$, in the female group were $0.815-0.932$, and in the male group were $0.829-0.921$. The reliability coefficients for the dimensions in the whole group were 0.667-0.856, in the female group were 0.644-0.868, and in the male group were $0.665-0.837$. The correlation coefficients between employee's job performance and the dimensions of the inventory ranged from -0.004 to -0.271 , and between factors from 0.086 to -0.214 . The correlation coefficients between employee's job satisfaction and the dimensions of the inventory ranged from -0.030 to -0.243 , and between factors from 0.086 to -0.214 . The correlation coefficient between job performance and job satisfaction was calculated 0.403

Secondly, multiple linear regression analyses were conducted in order to determine effects of personality traits in predicting job performance and job satisfaction. Results showed that, Assertiveness, Tolerance, Responsibility / Deliberateness, Self Assuredness, Sensitivity, and Openness to Newness dimensions and Extraversion, Agreeableness, Conscientiousness, and Emotional Instability factors significantly predict the job performance evaluations. However, Liveliness, Interaction, Calmness, Agreement, Soft Heartedness / Altruism, Orderliness, Compliance with the Rules, Excitement Seeking, Emotional Lability, Proneness to Anxiety, and Analytical Thinking dimensions and Openness to Experience factor found to be ineffective in predicting job performance evaluations.

The results for job satisfaction indicate that Liveliness, Interaction, Calmness, Orderliness, Compliance with the Rules, Responsibility / Deliberateness, Self Assuredness, and Sensitivity dimensions and all of the factors is significant predictors. However, Assertiveness, Tolerance, Agreement, Soft Heartedness / Altruism, Excitement Seeking, Emotional Lability, Proneness to Anxiety, Analytical Thinking, and Openness to Newness dimensions found to be ineffective in predicting job satisfaction.

Afterwards, based on their job performance $(M=4.07, S D=0.77)$ and job satisfaction levels $(\mathrm{M}=3.87, \mathrm{SD}=1.02)$, subjects were categorized into four groups: Low Performance - Low Satisfaction (55.4\%), Low Performance - High Satisfaction (13.0\%), High Performance - Low Satisfaction (12.6\%), and High Performance - High Satisfaction (19.0\%). Gender and job performance-job satisfaction groups ( 2 x 4) were compared in terms of 5 factors and 17 dimensions separately with MANOVA.

When gender differences are compared in terms of personality dimensions, females' mean scores found to be significantly higher than males' on the Liveliness, Assertiveness, Tolerance, Soft Heartedness / Altruism, Orderliness, Responsibility / Deliberateness, Emotional Lability, Proneness to Anxiety, Self Assuredness, Analytical Thinking, Sensitivity, and Openness to Newness dimensions, while males scored significantly higher than females only on the Calmness and Agreement dimensions. In addition, females scored higher on the Extraversion, Conscientiousness, Emotional Instability, and Openness to Experience factors. There were no significant differences found on the Agreeableness factor between gender groups.

\section{Conclusion}

The aim of the present study was to determine which personality traits are affective in predicting job performance and job satisfaction. The mean scores of the subjects were subjected to regression analysis and MANOVA, and presented separately for the factors and 17 dimensions. It was observed that results obtained from sub-dimensions have provided more detailed information compared to factors. Together these findings allow comparisons across studies that based on other theoretical models apart from the Five Factor Model of Personality. Respectively, results presented here for factors allow comparisons between findings obtained from different measures of personality across studies, and establish a cultural framework. Another conclusion can be drawn from the present study is that different statistical techniques may offer contradictory findings on the same subject. Although regression and variance analyses indicate similar results, there are differences between the two methods in detail. 


\section{References}

Alessandri, G., \& Vecchione, M. (2012). The higher-order factors of the Big Five as predictors of job performance. Personality and Individual Differences, 53(6), 779-784.

Avery, R. E., Smillie, L. D., \& Fife-Schaw, C. R. (2015). Employee achievement orientations and personality as predictors of job satisfaction facets. Personality and Individual Differences, 76, 56-61.

Barrick, M. R., \& Mount, M. K. (1991). The Big Five personality dimensions and job performance: A meta-analysis. Personnel Psychology, 44(1), 1-26.

Barrick, M. R., Mount, M. K., \& Judge, T. A. (2001). Personality and performance at the beginning of the new millennium: What do we know and where do we go next? International Journal of Selection and Assessment, 9(1-2), 9-30.

Barrick, M. R., Stewart, G. L., \& Piotrowski, M. (2002). Personality and job performance: Test of the mediating effects of motivation among sales representatives. Journal of Applied Psychology, 87(1), 43-51.

Bhatti, A. M., Mohamed Battour, M., Rageh Ismail, A., \& Pandiyan Sundram, V. (2014). Effects of personality traits (Big Five) on expatriates adjustment and job performance. Equality, Diversity and Inclusion: An International Journal, 33(1), 73-96.

Blickle, G., Meurs, J. A., Wihler, A., Ewen, C., Merkl, R., \& Missfeld, T. (2015). Extraversion and job performance: How context relevance and bandwidth specificity create a non-linear, positive, and asymptotic relationship. Journal of Vocational Behavior, 87, 80-88.

Blickle, G., Meurs, J. A., Zettler, I., Solga, J., Noethen, D., Kramer, J., \& Ferris, G. R. (2008). Personality, political skill, and job performance. Journal of Vocational Behavior, 72(3), 377-387.

Christen, M., Iyer, G., \& Soberman, D. (2006). Job satisfaction, job performance, and effort: A reexamination using agency theory. Journal of Marketing, 70(1), 137-150.

Costa, P. T., McCrae, R. R., \& Holland, J. L. (1984). Personality and vocational interests in an adult sample. Journal of Applied Psychology, 69(3), 390-400.

Guion, R. M., \& Gottier, R. F. (1965). Validity of personality measures in personnel selection. Personnel Psychology, 18(2), 135-164.

Judge, T. A., \& Zapata, C. P. (2015). The person-situation debate revisited: Effect of situation strength and trait activation on the validity of the Big Five personality traits in predicting job performance. Academy of Management Journal, 58(4), 1149-1179.

Judge, T. A., Heller, D., \& Mount, M. K. (2002). Five-Factor Model of personality and job satisfaction: A meta-analysis. Journal of Applied Psychology, 87(3), 530-541.

Judge, T. A., Weiss, H. M., Kammeyer-Mueller, J. D., \& Hulin, C. L. (2017). Job attitudes, job satisfaction, and job affect: A century of continuity and of change. Journal of Applied Psychology, 102(3), 356-374.

Karim, N. H. A. (2017). Investigating the correlates and predictors of job satisfaction among Malaysian academic librarians. Malaysian Journal of Library and Information Science, 13(2), 69-88.

Mount, M. K., Barrick, M. R., \& Stewart, G. L. (1998). Five-Factor Model of personality and performance in jobs involving interpersonal interactions. Human Performance, 11(2-3), 145-165.

Ozer, D. J., \& Benet-Martinez, V. (2006). Personality and the prediction of consequential outcomes. Annual Review of Psychology, 57, 401-421.

Rothmann, S., \& Coetzer, E. P. (2003). The Big Five personality dimensions and job performance. SA Journal of Industrial Psychology, 29(1), 68-74.

Rothstein, M. G., \& Goffin, R. D. (2006). The use of personality measures in personnel selection: What does current research support? Human Resource Management Review, 16(2), 155-180.

Salgado, J. F. (1997). The Five Factor Model of personality and job performance in the European community. Journal of Applied Psychology, 82(1), 30-43.

Saltukoğlu, G., \& Tatar, A. (2018). İş performansının öngörülmesinde kişilik ölçümünün rolü: Öğretmen örneği. Journal of Human Sciences, 15(1), 619-634.

Schmitt, N., Gooding, R. Z., Noe, R. A., \& Kirsch, M. (1984). Metaanalyses of validity studies published between 1964 and 1982 and the investigation of study characteristics. Personnel Psychology, 37(3), 407-422.

Somer, O., Korkmaz, M., \& Tatar, A. (2002). Beş Faktör Kişilik Envanterinin geliştirilmesi-I: Ölçek ve alt ölçeklerin oluşturulması. Türk Psikoloji Dergisi, 17(49), 21-37.

Somer, O., Korkmaz, M., \& Tatar, A. (2004). Kuramdan Uygulamaya Beş Faktör Kişilik Modeli ve Beş Faktör Kişilik Envanteri (5FKE). Ege Üniversitesi Basımevi, İzmir. 
Tatar, A., Şahintürk, H., Saltukoğlu, G., \& Telvi, S. (2013). Tiyatro oyuncularının Beş Faktör Modeli çerçevesinden kişilik özelliklerinin incelenmesi ve meslek grubu profillerinin oluşturulması. Türk Psikoloji Dergisi, 28(72), 1-16.

Tatar, A., Saltukoğlu, G., \& Teoman, D. D. (2017). Çalışan genç kadınların kişilik profilleri ve bireycilik-toplulukçuluk özellikleri. Iş̧'te Davranış Dergisi, 2(1), 34-45.

Tatar, A., Saltukoğlu, G., Dal, G., \& Atay, B. (2013). Eczacıların Beş Faktör Modeli çerçevesinden kişilik özelliklerinin incelenmesi ve meslek grubu profillerinin oluşturulması. FSM İlmî Araştırmalar Insan ve Toplum Bilimleri Dergisi, 2, 323-341.

Wright, T. A., \& Cropanzano, R. (2000). Psychological well-being and job satisfaction as predictors of job performance. Journal of Occupational Health Psychology, 5(1), 84-94.

Zhao, H., \& Seibert, S. E. (2006). The Big Five personality dimensions and entrepreneurial status: A meta-analytical review. Journal of Applied Psychology, 91(2), 259-271. 